\title{
First insights on Lake General Carrera/Buenos Aires/Chelenko water balance
}

\author{
G. Zambrano ${ }^{1}$, R. Abarca del Rio ${ }^{1}$, J.-F. Cretaux ${ }^{2}$, and B. Reid ${ }^{3}$ \\ ${ }^{1}$ Departamento de Geofísica (DGEO), Universidad de Concepción, Concepción, Chile \\ ${ }^{2}$ LEGOS (UMR5566), Observatoire Midi-pyrénées, Toulouse, France \\ ${ }^{3}$ Centro de Investigación en Ecosistemas de la Patagonia (CIEP), Universidad Austral de Chile, Bilbao 449, Coyhaique, Chile
}

Received: 19 May 2009 - Revised: 1 July 2009 - Accepted: 8 July 2009 - Published: 17 December 2009

\begin{abstract}
Lago General Carrera (Chile) also called Lago Buenos Aires (Argentina) or originally Chelenko by the native habitants of the region is located in Patagonia on the Chilean-Argentinean border. It is the largest lake in Chile with a surface area of $1850 \mathrm{~km}^{2}$. The lake is of glacial/tectonic origin and surrounded by the Andes mountain range. The lake drains primarily to the Pacific Ocean to the west, through the Baker River (one of Chile's largest rivers), and intermittently eastward to the Atlantic Ocean. We report ongoing results from an investigation of the seasonal hydrological cycle of the lake basin. The contribution by river input through snowmelt from the Andes is of primary importance, though the lack of water input by ungaged rivers is also critical. We present the main variables involved in the water balance of Lake General Carrera/Buenos Aires/Chelenko, such as influent and effluent river flows, precipitation, and evaporation, all this based mostly in in-situ information.
\end{abstract}

\section{Introduction}

Lake General Carrera/Buenos Aires/Chelenko (LGC/BA/C) is the largest lake in Chile and the second largest lake in South America, and based on a recent global review of lake characteristics (Kalff (2001)) it is possibly the 13th largest and 7th deepest in the world. There are few scientific investigations on the biology, hydrology, and physical limnology of this large and potentially very significant lake. Basic hydrologic data exist in raw form from a network of sensors maintained by the Directorate General Water (DGA in Spanish acronym). Meanwhile the lake and its catchments are still

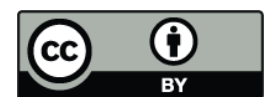

Correspondence to: G. Zambrano (gzambran@udec.cl) strongly influenced by perhaps the largest system of temperate glaciers and ice fields in the world (North Patagonian Icefield, Warren et al., 1993), and whose influence will possibly diminish with global climate change.

Region Aysen is divided into four climatic zones (IGM (1998)) (see Fig. 1): (a) a cold wet temperate, (b) a transAndean merging into steppe, (c) a sub-zero high-altitude climate, and finally (d) a cold steppe climate. The region presents a highly dynamic geography that underscores the interaction between the topography due to high altitudes who act as a barrier to wind and precipitation (Walsh, 1994), ocean influence and atmospheric circulation (Townley, 2007). The atmospheric circulation is dominated by westerly winds, low pressure, frontal systems (Seluchi et al., 2000) and the South Pacific subtropical anticyclone (Rodwell and Hoskins, 2001).

An example of the complexity of the regional climate is high longitudinal precipitation gradient around the lake, approximately $1350 \mathrm{~mm} / \mathrm{yr}$, with $1470 \mathrm{~mm} / \mathrm{yr}$ in the coast and $120 \mathrm{~mm} / \mathrm{yr}$ in the east zone (Townley, 2007). The temperature is dominated by the oceanic influence on the coast, the microclimate in the interior under the influence of lakes, low temperatures in high altitude areas and a large temperature variation in the steppe zone (Jobbágy et al., 1995; Paruelo et al., 1969). On account of these variations in temperature and precipitation, snow cover has a seasonal pattern, with movements influenced by temperature variations $(73 \%$ of the variance explained) and precipitation in the area (López et al., 2008).

The purpose of this paper is to develop a synthesis of the existing hydrologic data, interpret the sources of variability over seasonal time scales, conduct a basic hydrologic mass balance, and propose recommendations that address the uncertainty and data gaps. Because of its limitations, this research intends to give a first insight on the lake level variability, and is a first step towards a better understanding of the

Published by Copernicus Publications on behalf of the European Geosciences Union. 


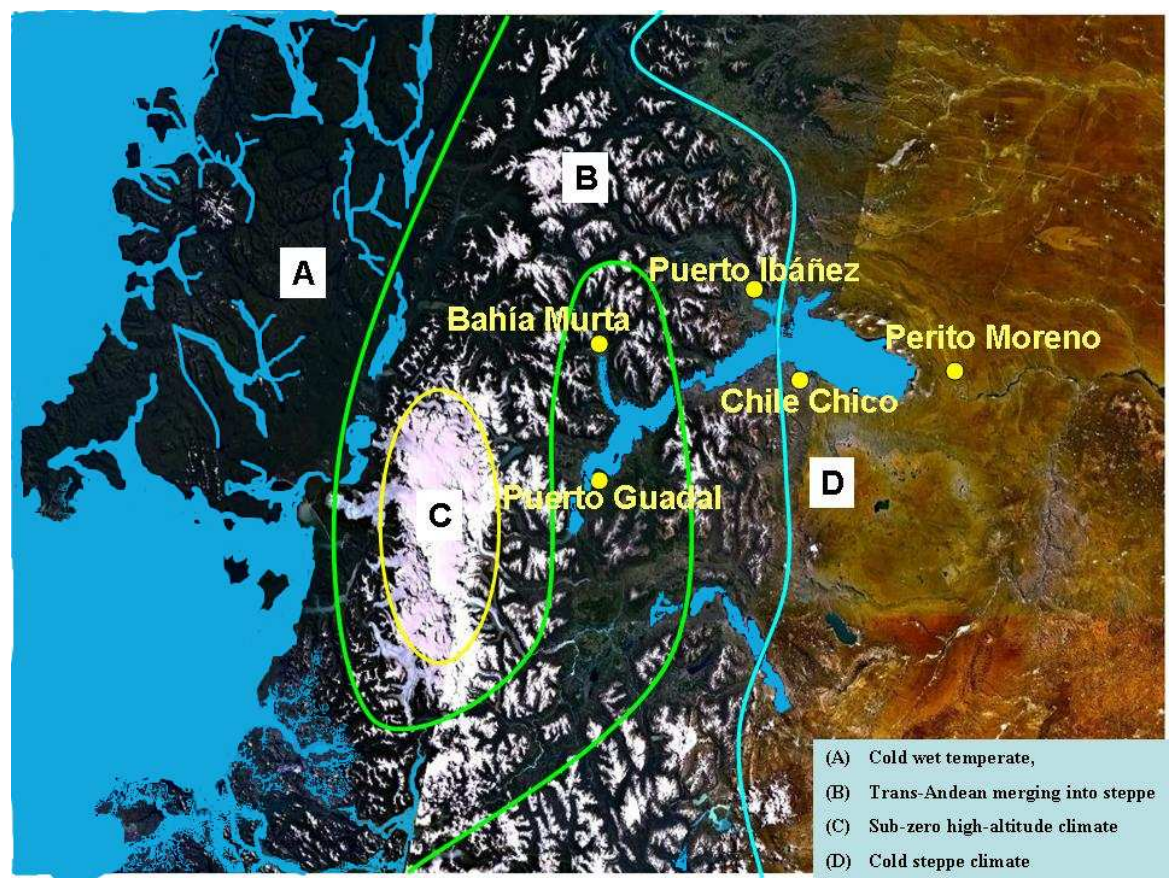

Fig. 1. Study site, showing the location of the in situ monitoring stations and the main climatic zones.

whole basin hydrological balance and probable influences by local and remote climate variability.

The paper is presented as follows. Description of data and statistical methods used for analysis are explained in Sect. 2 and results are presented in Sect. 3. Finally Sect. 4 provides discussion and conclusions.

\section{Data and methodology}

\subsection{Data Set}

The in situ daily and monthly data set (see Table 1) (precipitation, temperature, evaporation, river flows, lake level) around the lake, were provided by the DGA (Directorate General Water) of Aysén region. From this data set, in which some time series goes back to 1985, we choose the period in which most of the time series were complete, i.e., the 2000 2006 time span. The time series were then processed through interpolation in order to complete small gaps in the daily time series, before constructing monthly means, and then a monthly mean climatology for he period (2000-2006).

We note here that although Lake level in Puerto Guadal only covers years 2003-to-2006, its variability is exactly the same as registered in Chile Chico $\left(r^{2}=0.95\right)$. Both were also corroborated with lake level by satellite altimetry (Crétaux et al., 2006) data $\left(r^{2}=0.81\right.$ and $r^{2}=0.77$ respectively with Chile Chico and Puerto Guadal). It is also the case for the flows of river Baker, being the sole river output it follows exactly the lake level variability $\left(r^{2}=0.89\right.$ and $r^{2}=0.96$ respectively with Chile Chico and Puerto Guadal lake level).

\subsection{Method}

To complete a lake water balance computation, we need volumes of water inputs and outputs from precipitation and evaporation. We therefore employed the Thiessen polygons method (Hartkamp et al., 2001), which allows computing the precipitation (and evaporation) water volumes average in the basin through the following expression:

$P_{m}=\frac{\sum_{i=1}^{N} P_{i} A_{i}}{\sum_{i=1}^{N} A_{i}}$

where $P_{i}$ is the precipitation of station $i, A_{i}$ is the area of influence of the station $i, N$ is the number of stations and $P_{m}$ is the average rainfall in the basin. Errors due to this estimation (usually due to over or under estimation of areas of influence) are considered within the margin of error of computing the water balance. The balance is estimated in units of volume, so each of the variables involved in estimating the balance should be converted to units of volume. This is computed monthly over the climatology data. Of course, the closer to the in situ station, the greater the accuracy of the determined amounts of precipitation and evaporation water inputs and outputs, respectively. 
Table 1. Meteorological and river discharge monitoring stations. D and M refers to daily and monthly mean values, respectively, and dates refer to the range of data availability. All river discharge stations are inputs to the system, except for River Baker which is the sole output

\begin{tabular}{|c|c|c|c|c|}
\hline Stations & Location & Weather & River discharge (daily mean) $\left[\mathrm{m}^{3} / \mathrm{s}\right]$ & Lake Level (daily mean) [m] \\
\hline \multirow[t]{4}{*}{ Bahía Murta } & $46^{\circ} 27^{\prime} \mathrm{S}$ & 1993-2007 & 1985-2006 & \\
\hline & $72^{\circ} 40^{\prime} \mathrm{W}$ & D Pre $[\mathrm{mm}] \mathrm{M}$ & River Murta & - \\
\hline & & Temp $\left[{ }^{\circ} \mathrm{C}\right] \mathrm{M}$ & (50 km length) & \\
\hline & & Evap $[\mathrm{mm}]$ & & \\
\hline \multirow[t]{4}{*}{ Chile Chico } & $46^{\circ} 32^{\prime} \mathrm{S}$ & 1993-2004 & 1995-2004 & 2000-2006 \\
\hline & $71^{\circ} 44^{\prime} \mathrm{W}$ & D Pre $[\mathrm{mm}]$ & River Jeinimeni (40 km length) & \\
\hline & & M Temp $\left[{ }^{\circ} \mathrm{C}\right]$ & $1995-2006$ & \\
\hline & & M Evap mm] & River El Baño (18 km length) & \\
\hline \multirow[t]{4}{*}{ Puerto Ibáñez } & $46^{\circ} 18^{\prime} \mathrm{S}$ & 1993-2007 & $1985-2006$ & \\
\hline & $71^{\circ} 56^{\prime} \mathrm{W}$ & D Pre $[\mathrm{mm}]$ & River Ibáñez (88 km length) & - \\
\hline & & M Temp $\left[{ }^{\circ} \mathrm{C}\right]$ & & \\
\hline & & M Evap [mm] & & \\
\hline \multirow[t]{2}{*}{ Perito Moreno } & $46^{\circ} 31^{\prime} \mathrm{S}$ & $1971-2008$ & & \\
\hline & $71^{\circ} 00^{\prime} \mathrm{W}$ & M Pre $[\mathrm{mm}]$ & - & - \\
\hline \multirow[t]{2}{*}{ Puerto Guadal } & $46^{\circ} 50^{\prime} \mathrm{S}$ & 1993-2007 & & 2003-2006 \\
\hline & $72^{\circ} 43^{\prime} \mathrm{W}$ & M Pre $[\mathrm{mm}]$ & - & \\
\hline \multirow[t]{2}{*}{ Lago Bertrand } & $47^{\circ} 04^{\prime} \mathrm{S}$ & & 2003-2006 & \\
\hline & $72^{\circ} 47^{\prime} \mathrm{W}$ & - & River Baker (370 km length) & - \\
\hline
\end{tabular}

Table 2. Accumulated water per year

\begin{tabular}{ll}
\hline Variable & Accumulated $\left[\mathrm{km}^{3}\right]$ \\
\hline Precipitation & $3.10(1478[\mathrm{~mm} / \mathrm{yr}])$ \\
Evaporation & $0.66(534.7[\mathrm{~mm} / \mathrm{yr}])$ \\
Rivers inflow & 9.64 \\
Rivers outflow & 18.99 \\
\hline
\end{tabular}

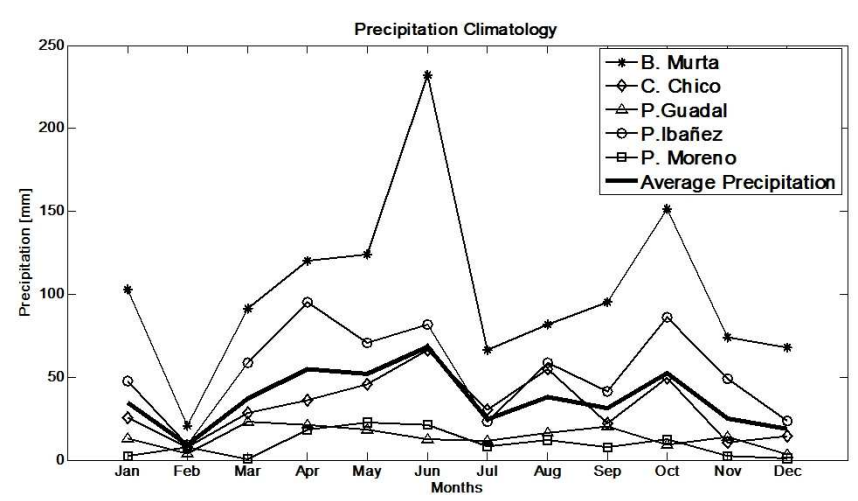

Fig. 2. Monthly mean precipitation (accumulated $\mathrm{mm} / \mathrm{month}$ ) for the different in-situ meteorological stations and the averaged monthly mean precipitation over the lake.
Table 3. Historic water balance for basin river Baker (1951 to 1980: Water Balance, DGA-1987)

\begin{tabular}{lr}
\hline Variables & Value [mm/year] \\
\hline Precipitation & 1759 \\
Total Runoff & 1336 \\
Evaporation (lakes, open water) & 85.9 \\
Evapotranpiration & 336 \\
\hline
\end{tabular}

\section{Results}

\subsection{Seasonal cycles}

Precipitation: an annual cycle of precipitation, whose maxima coincided with the austral winter season (JuneSeptember) is observed in some of the five in situ stations (Fig. 2) along the lake. Their diversity illustrates the extreme complexity of microclimates surrounding the lake, as presented in the introduction. For example, measurements of Bahía Murta precipitation presents the greatest annual accumulation, with maxima in June and October, corresponding with winter and spring precipitations and a well pronounced minimum during February (summer). Although the other stations such as Chile Chico, Puerto Ibáñez and Perito Moreno present lesser annual accumulated precipitations (by half), it shows important variance from April to October (mid autumn to mid spring) and less precipitation during summer. Finally Puerto Guadal presents its peak rainfall during autumn and early spring, and is lower in winter and 


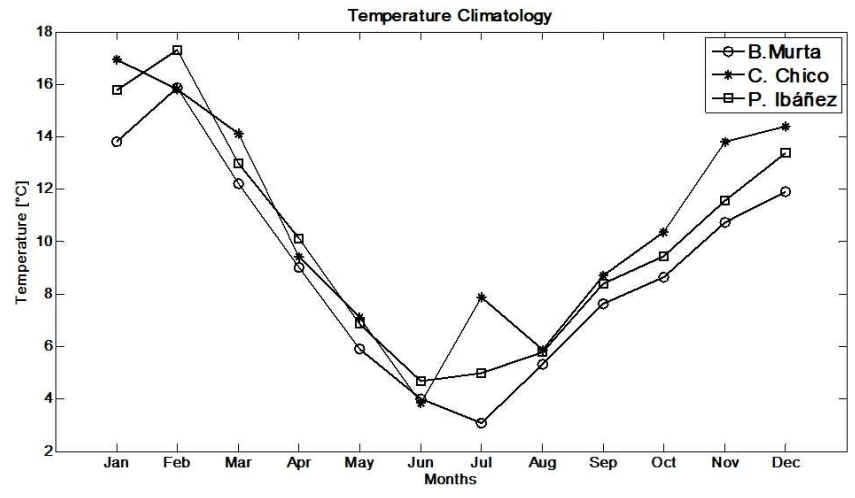

Fig. 3. Monthly mean air temperature for the different in-situ meteorological stations.

summer. However its contribution is the less important. As a result, the accumulated monthly mean rainfall over the lake (Fig. 2), computed following the method described in Sect. 2, reaches its highest values during mid autumn to winter (April to June). It shows also some variability during spring, and precipitation during summer.

Temperature: the air surface temperature measurement over the 3 stations (Table 1) presents a similar pattern: a marked annual cycle peaking in summer and minimum in winter (Fig. 3). Indeed the distribution of temperature highlights also the complexity of microclimates in the zones; high temperatures in Chile Chico, reaching $30^{\circ} \mathrm{C}$ in summer and a winter minima at Perito Moreno $\left(-10^{\circ} \mathrm{C}\right)$.

Evaporation: the measured evaporation over the 3 stations (Table 1) along the lake coasts differs substantially in amplitude, showing a $314 \mathrm{~mm}$ summer (January) evaporation in Chile Chico and minimum evaporation in Bahía Murta of $1 \mathrm{~mm}$ in winter (June). Evaporation tracks with air surface temperature (figure not shown), i.e., a marked annual cycle that peaks in summer and minima in winter. The computed global lake evaporation using the same method as for computing global precipitation input over the lake (Thiessen method, see Sect. 2), gives an annual accumulation of about $534.7 \mathrm{~mm} / \mathrm{yr}\left(0.66 \mathrm{~km}^{3}\right)$. The historical (1951-1980) annual accumulated evapotranspiration over the entire Baker Basin as reported by Lobos et al. (1987a) is $336 \mathrm{~mm} / \mathrm{yr}$, while the reported historical evaporation for open water is about $85.9 \mathrm{~mm} / \mathrm{yr}$ (Table 3). This gives insight on the fact that the measurement stations along the lake are measuring evapotranspiration rather than open water evaporation. Regardless of the method of estimation, the annual water volume loss by evaporation is not meaningful when compared with the outflowing water by the Baker river (see Table 2 and Fig. 7).

Lake level: all these water inputs and outputs give rise to the lake level variability, or change in lake storage (Fig. 4). The lake level shows strong correlation across both sides of the lake (correlation in Sect. 2.1), and agrees with the altime-
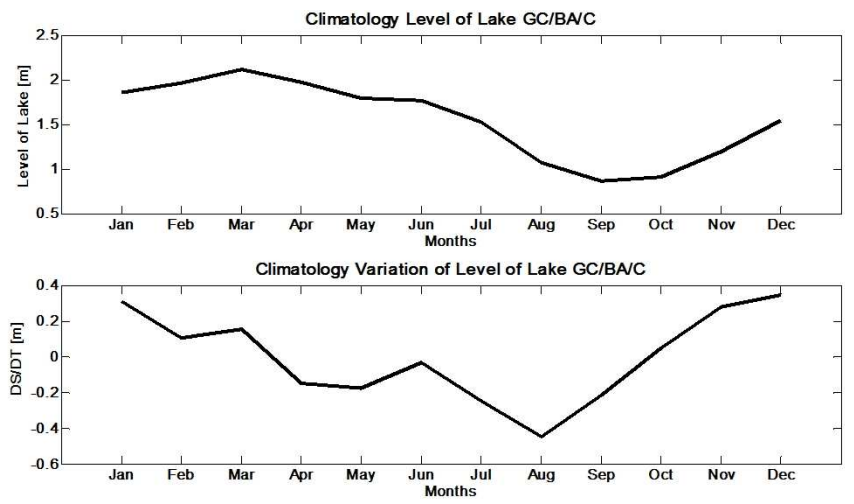

Fig. 4. In situ Lake Level associated variability. The upper panel shows monthly mean lake level. The lower panel the monthly mean lake level variation.

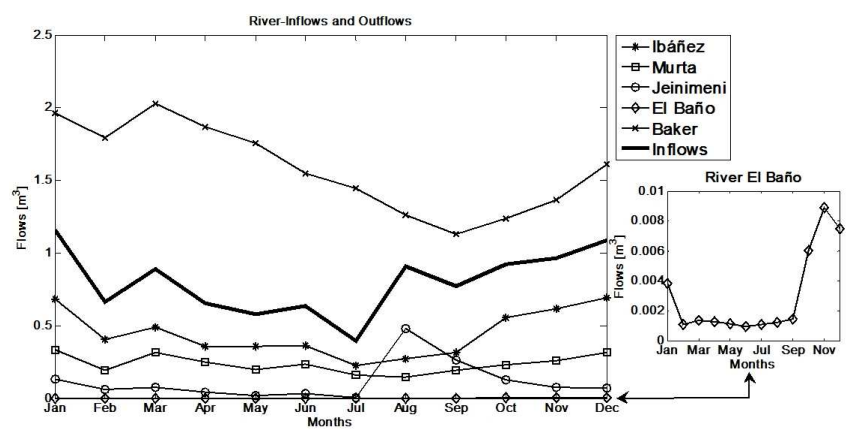

Fig. 5. Monthly mean river discharges and total fluvial inputs into Lake General Carrera/Buenos Aires/Chelenko.

ter measurements (correlation in Sect. 2.1). The lake level shows a maximum during summer and minimum in winter, respectively 2.2 and $1.2 \mathrm{~m}$, i.e., an annual range of about $1 \mathrm{~m}$, corresponding with a maximum volume change through the year of about $1.85 \mathrm{~km}^{3}$. Indeed volume variation depends on bathymetry. However, since the only reported bathymetry (Murdie et al., 1999) covers only the Chilean side of the Lake (i.e., from $71^{\circ} 43^{\prime} \mathrm{W}$ to $72^{\circ} 47^{\prime} \mathrm{W}$, correspondingly to 970 square kilometers), we assumed over a meter a constant surface over depth, i.e. the surface covered at the superficies is equivalent to the one at a $1 \mathrm{~m}$ depth.

Rivers: variations in the flow of the rivers are shown in Fig. 5.

Ibáñez and Murta rivers, that originates in the highs of the Andes in Huemules $\left(45^{\circ} 56^{\prime} \mathrm{S}, 72^{\circ} 52^{\prime} \mathrm{W}\right)$ and Erasmo $\left(46^{\circ} 08^{\prime} \mathrm{S}, 73^{\circ} 03 \mathrm{~W}\right)$ snowdrifts respectively and then flow eastward through the mountains down to the lake in a course of about 88 and $50 \mathrm{~km}$ approximately (Fig. 6). The two others rivers (Jenimeni and El Baño) originates respectively over the south eastern side of the lake. River Jenimeni originates in a mountainous lake with the same name (El Jeinimeni is 


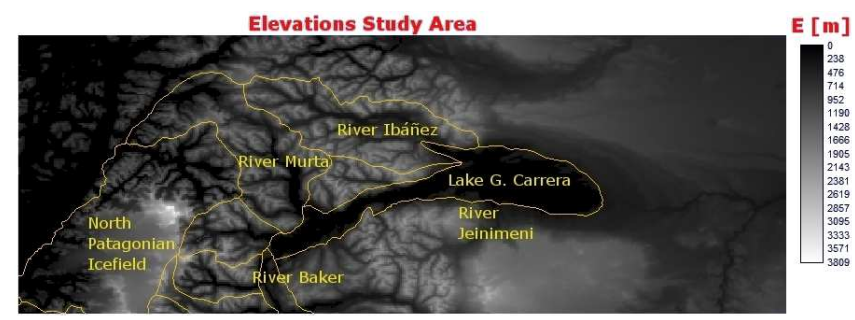

Fig. 6. Main rivers within the basin of Lake General Carrera/Buenos Aires/Chelenko.

located at $46^{\circ} 51^{\prime} \mathrm{S}-72^{\circ} 00^{\prime} \mathrm{W}$ ), while River El Baño originates around $46^{\circ} 37 \mathrm{~S}-72^{\circ} 03^{\prime} \mathrm{W}$. Both rivers flow northward through the mountains down to the lake in a course of about 40 and $18 \mathrm{~km}$ approximately.

Both Ibáñez and Murta river flows shows an annual cycle with maxima during summer (January) and minima during winter (July). This annual cycle is less prominent in river Murta. Both present additional peaks in March and August. The highest peak in January is due to summer snow melting over the Andes, and agrees with results by López et al. (2008) whom investigated the snowmelt seasonal cycle, particularly over the Northern Icefield. Note that the air temperature also peaks in early autumn (March) and early spring (September and October) (see Fig. 3), that also coincides with the river flow rates, and can also be associated with snow melting. In addition, satellite precipitation fields (resolution $25 \mathrm{~km}$, Kubota et al., 2007) over the mountains where the rivers originate shows peaks in March and August (not shown). Therefore, rainfall also plays a role, though it is not the most important contribution.

Jeinimeni and El Baño rivers peak between October and November and are almost uniform over the rest of the year. Although the pluvial regime could be the source of main variability, the timing of the water flow in spring suggests that it could also be fed partly by spring nival regimes following winter accumulation.

Finally, being the only outflow from the lake, River Baker exits from Lago Bertrand (fed directly by acronyms LGC/BA/C) presenting its annual peak in late summer early autumn (January to March) and minimum in September (early spring), similar to the annual cycle of the General Carrera lake level (see Fig. 4 and below).

\subsection{Water balance}

The water balance is given by the expression (Custodio and Llamas, 1983):

$$
\frac{D V}{D T}=\underbrace{P+Q_{\mathrm{SE}}}_{\mathrm{IN}}-\underbrace{\left(E+Q_{\mathrm{SS}}\right)}_{\text {OUT }} \pm \underbrace{G}_{\text {Groundwater }} \pm \underbrace{\epsilon}_{\text {error }}
$$

Where $D V / D T$ is the volume variation of the lake, $P$ is precipitation, $Q_{\mathrm{SE}}$ are inputs of surface water, $E$ is evaporation,
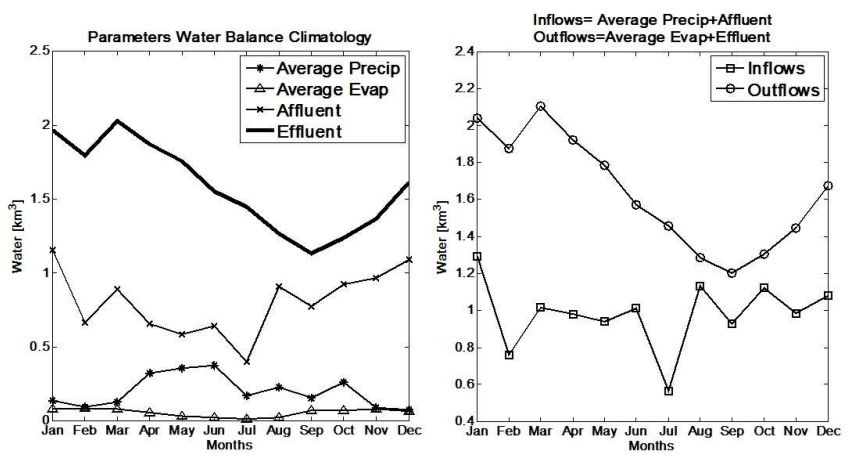

Fig. 7. Mean monthly water balance. (A) Inflows from rivers $(-x-$ ) and precipitation $(-*-)$, outputs from evaporation $(-\triangle-)$ and River Baker (-). (B) Total inflows (- $\square-$ ) and outflows (-o-).

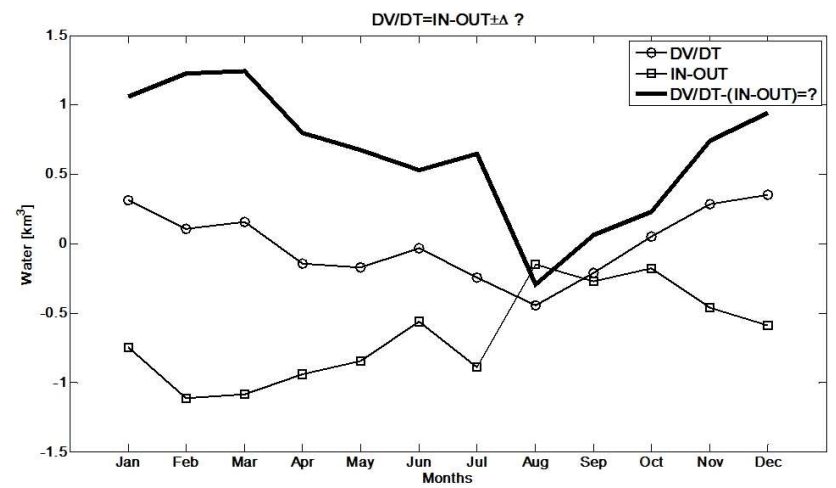

Fig. 8. Total water balance. Difference between total inflow and total outflow (- $\square$-), lake volume variation (-o-) and DV/DT-(IN$\mathrm{OUT})=\Delta ?(-)$.

$Q_{\text {SS }}$ are outputs of surface water, groundwater is $G$ (incoming and outgoing) and $\epsilon$ is the error. We will assume first, to compute a first guess of the water balance, a small error, i.e. negligible when compared to the magnitude of other variables. However, it is clear for us (see the discussion section) that there is a significant amount of unmonitored catchments, and the larger the area of the ungaged basins, the larger the error.

The accumulated annual water volume input by rainfall directly into the lake is about $3.1 \mathrm{~km}^{3}(1478 \mathrm{~mm} / \mathrm{yr}$, see Sect. 2 and Table 2), while that attributed to river flows is about $9.64 \mathrm{~km}^{3}$. Therefore the contribution by rainfall directly into the lake is one third that of river inflows (Table 2), i.e., not negligible. Instead evaporation when compared to river baker outflows (Table 2), is negligible (given that already evapotranspiration is negligible), and therefore outgoing water is mostly driven by flow in River Baker. This is summarized in Fig. 7, where the average evaporation over the lake does not change the pattern of the outgoing water, while the averaged precipitation does change that of the incoming water fluxes. 
The comparison of the outgoing water $\left(18.99 \mathrm{~km}^{3}\right)$ with regards to the total (rivers + precipitation into lake) incoming water $\left(10.74 \mathrm{~km}^{3}\right)$ shows that $43 \%$ of the total incoming water is unaccounted for. The seasonal cycle of the difference between lake volume variability (DV/DT) and all water into the lake (Fig. 4), shows that the missing water does present a cycle with a maximum in January through March and minima in August (Fig. 8).

\section{Discussion and conclusions}

We investigated the seasonal water balance of the west-east oriented $200 \mathrm{~km}$ long Lake Carrera/Buenos Aires/Chelenko. In situ, historical, and satellite data allowed us to characterize the main contributors to the lake and understand the lake level variability. Precipitation, through melting snow and rainfall into the basin, associated with four climatic zones with large differences in the precipitation patterns and which are crossed by the lake (Fig. 1) has a major impact in the water balance of the lake. The summer nival flow river regimes, arising from the western side Andean region, play a preponderant role into the river inflow into the lake, accompanied by a winter-spring probably pluvial-nival regime associated with the southern region of the lake. This gives insights into the seasonal cycle of the lake level variability.

It is interesting to note that the seasonal cycle of the missing water presents a maxima in summer that agrees with summer melted water, for example an influx regime similar to River Ibáñez. However, we note that the missing water also has a seasonal pattern with water inflows during winter and spring seasons, which indicates that some water must also arise with a seasonal flow regime similar River Jenimeni or River El Baño, which follow a southern lake nival-pluvial regime.

As a result the missing water must arise from the entire lake basin from both nival and pluvial regimes. This is in fact not surprising: a geographic investigation using a high-resolution regional map (Lobos et al., 1987a) shows that there are many rivers incoming into the lake, known or unknown (at least to our knowledge), which are still ungaged. For example, over the west and directly related with a glacier connected with North Icefield is river Soler which is a tributary to the lake Bertrand in the south western side of Lake LGC/BA/C at $46^{\circ} 58^{\prime} \mathrm{S}-72^{\circ} 52^{\prime} \mathrm{W}$. Between Puerto Ibáñez and Bahía Murta, there's also an ungaged river, the river Avellanos $\left(46^{\circ} 30^{\prime} \mathrm{S}, 72^{\circ} 10^{\prime} \mathrm{W}\right)$. Over the southern side, close to Chile Chico, there's at least three ungaged rivers that input into the lake at $46^{\circ} 33^{\prime} \mathrm{S}-72^{\circ} 14^{\prime} \mathrm{W}, 46^{\circ} 43^{\prime} \mathrm{S}-72^{\circ} 31^{\prime} \mathrm{W}$ and $46^{\circ} 46^{\prime} \mathrm{S}-72^{\circ} 36^{\prime} \mathrm{W}$. Clearly, there is a lot of surface water incoming into the lake. Other inputs are also possible, such as groundwater, which is currently unreported.
As a constraint on the water balance, we can calculate potential inputs based solely on precipitation. The entire Baker basin covers 26726 square kilometres (page 22, Lobos et al., 1987a) and about half may be associated to Lake Carrera basin (approximately 13000 squared kilometres). As an average estimate, we used the historically derived precipitation (Table 3, Lobos et al., 1987a) from the whole Baker basin, i.e., $1750 \mathrm{~mm} / \mathrm{yr}$. By subtracting the average historically derived evapotranspiration $336 \mathrm{~mm} / \mathrm{yr}$, we obtain the incoming runoff into the lake (assuming all water is transported instantaneously) which is $1423 \mathrm{~mm} / \mathrm{yr}$. When computed over the Carrera Basin, it gives a volume of about $18.49 \mathrm{~km}^{3}$, which is indeed comparable to the outflowing water reported for River Baker $\left(18.99 \mathrm{~km}^{3}\right)$. Note that by their computed runoff (which takes into account also lake evaporation; Table 3 ) it results in an amount of water of $17.40 \mathrm{~km}^{3}$. Of course both precipitation and evapotranspiration varies along the basin, and most probably underestimated in the case of precipitation, especially given that precipitation over the North Icefield could exceed $6000 \mathrm{~mm} / \mathrm{yr}$. The same may be true for evapotranspiration. However, this gives us insights on the fact that there's an amount of water incoming into the basin that is effectively unaccounted by the actual river inflows (close to half) into the lake.

Indeed this is only a first approximation of the total water balance. A correct analysis will first require de visu all the possible rivers and streams coming into the lake, and then attempt to gauge them or estimate their contribution. Groundwater may be a major contribution of mass flux of water to some lakes, for example shallow isolated lakes in glacial outwash plains (Magnusen et al., 2006). A rough estimate based on regional scale geologic mapping indicates that unconsolidated deposits, mostly fluvial, represent somewhere between 5 and 10 per cent of the lake shore interface. There are also considerable areas of volcanic rocks, including basalts, which are generally highly transmissive (Fetter, 2001). Analysis over the broader lake reveals that although the regional rock geology, as reported by plate 5 of Chilean Hydrogeological Map (Lobos et al., 1987b) (excluding the along river path, considered as highly permeable) favours surface flows, groundwater flow present a great potential. Thus groundwater inputs may therefore be significant in this lake. However given the extreme depth and volume of the lake, lack of direct estimates of groundwater inputs, the perils of estimating groundwater as the residual in mass-balance estimates (Winter, 1981) and the large uncertainty in ungauged river inputs, we conservatively propose that groundwater inputs are probably less than $10 \%$ of the overall water budget.

Finally, in parallel, a computer hydrological model of the basin could be another useful approach. For example, analysis such as the one reported by Pellicciotti et al. (2008) allowed them to estimate the amount of snow melted water over the highs of the Juncal Norte Glacier $\left(32^{\circ} 98^{\prime} \mathrm{S}\right.$, $70^{\circ} 11^{\prime} \mathrm{W}$ ) located in the upper Aconcagua River Basin, in the semi-arid Andes of central Chile. This same approach 
could give us an estimate of the amount of snow melted water compared to rainfall.

Although incomplete, due to the substantial lack of information on incoming water, the investigation of Lake Carrera/Buenos Aires/Chelenko water budget resulted in important information on the source of its variability. Given the large volume of water in its hydrological basin, the dependence of the River Baker basin on its variability, and finally its dependence on the summer snow melting over the Andes, the lake appears to be an important proxy for understanding the local hydroclimate variability as well as for monitoring future impact of climate changes over the whole basin. No doubt reconstruction of past lake level variability could also be useful for understanding the influence of remote climates on the Andean snow accumulation and hydrologic cycle and help us in determining the impact of future climates in the whole Baker hydrological basin.

Acknowledgements. We are highly indebted to Directorate General Water (DGA, Chile) of Coyhaique in the Aysen Region for the in situ data and support. Particularly to Mr. Juan Salas and Mr. Francisco Guzmán whom both sent us the required information and delivered us important insights on the lake basin variability. Mrs. G. M. Zambrano is funded by national CONICYT 21080378 grant (CONICYT Ph.D doctorate scolarship 21080378). This work was part of the ECOS C04U02 (Chile (DGEO)-France (LEGOS)) project Continental hydrology from a combination of altimetry, gravimetry and in-situ data. Application to the Andean Region.

Edited by: R. Garraud

Reviewed by: one anonymous referee

\section{References}

Custodio, E., and Llamas, M.: Hidrogeología Subterránea. Tomo I. Ediciones Omega, S. A. 2350 pp., 1983.

Crétaux J.-F. and Birkett, C.: Lake studies from satellite altimetry, C. R. Geoscience, 338, 1098-1112, doi:10.1016/J.crte.2006.08.002, 2006.

Fetter, C. W.: Applied Hydrogeology 4th ed., Prentice, 598 pp., 2001.

Hartkamp, A. D., De Beurs, K., Stein, A., and White J. W.: Interpolation Techniques for Climate Variable, NRG-GIS Series 99-01, Mexico, D. F., CIMMYT 1999.

IGM - Instituto Geográfico Militar: Atlas geográfico de Chile: para la educación. 1998.

Jobbágy E., Paruelo, J. and León, L.: Estimación del régimen de precipitación a partir de la distancia de la cordillera en el noroeste de la Patagonia, Ecología Austral, 5, 47-53, 1995.
Kalff, J.: Limnology, Prentice Hall, Upper Saddle River, New Jersey, USA, 2001.

Kubota, T., Shige, S., Hashizume, H., Aonashi, K., Takahashi, N., Seto, S., Hirose, M., Takayabu, Y. N., Nakagawa, K., Iwanami, K., Ushio, T., Kachi, M., and Okamoto, K.: Global Precipitation Map using Satelliteborne Microwave Radiometers by the GSMaP Project: Production and Validation, IEEE T. Geosci. Remote, 45(7), 2259-2275, 2007.

Lobos, E., García, E., and Peña, H.: Balance Hídrico de Chile, Dirección general de Aguas, Ministerio de obras Públicas, Gobierno de Chile, 58 pp., 1987a.

Lobos, E., García, E., and Peña, H.: Mapa Hidrogeológico de Chile, Dirección general de Aguas, Ministerio de obras Públicas, Gobierno de Chile, 8 pp., 1987b.

López, P., Sirguey, P., Arnaud, Y., Pouyaud, B., and Chevallier, P.: Snow cover monitoring in the Northern Patagonia Icefield using MODIS satellite images (2000-2006), Global Planet. Change, 61, 103-116. 2008.

Magnusen, J. J., Kratz, T. K., and Benson, B. J. (Eds.): Long-term Dynamics of Lakes in the Landscape, Oxford University Press, USA, 464 pp., 2006.

Murdie, R. E., Pugh, D. T., and Styles, P.: A lightweight, portable, digital probe for measuring the thermal gradient in shallow water sediments, with examples from Patagonia, Geo-Mar. Lett., 18, 315-320, 1999.

Paruelo, J., Beltrán, A., Jobbágy, E., Sala, O., and Golluscio, R.: The climate of Patagonia: general patterns and controls on biotic processes, Ecologa Austral, 8, 85-101. 1969.

Pellicciotti, F., Helbing, J., Rivera, A., Favier, V., Corripio, J., Araos, J., Sicart, J.-E., and Carenzo, M.: A study of energy balance and melt regime on Juncal Norte Glaciar, semi-arid Andes of central Chile using melt models of different complexity, Hydrol. Process., 22, 3980-3997, 2008.

Rodwell, M. J. and Hoskins, B. J.: Subtropical Anticyclones and Summer Monsoons, J. Climate, 14, 3192-3211. 2001.

Seluchi, M. and Marengo, J.: Tropical-Midlatitude Exchange of Air Masses During Summer and Winter in South America: Climatic Aspects and Examples of Intense Events, Int. J. Climatol., 20, 1167-1190, 2000.

Townley, B.: Línea de Base del Medio Físico del Proyecto Hidroeléctrico Aysén. Capítulo 2: Clima y Meteorología, 75 pp., 2007.

Walsh, K.: On the Influence of the Andes on the General Circulation of the Southern Hemisphere, J. Climate, 7, 1019-1025, 1994.

Warren, C. R. and Sugden, D. E.: The Patagonian Icefields: A Glaciological Review, Arctic and Alpine Research, 25(4), 316331, 1993.

Winter, T. C.: Uncertainties in Estimating the Water Balance of Lakes, Water Resour. Bull., 17(1), 82-115, February 1981. 